Volume 13 Number 1, January-March 2019: pp. 19-30. Copyright (c) 2019 FIAT JUSTISIA. Faculty of Law, Lampung University, Bandarlampung, Lampung, Indonesia. ISSN: 1978-5186 | e-ISSN: 2477-6238.

Fiat Justisia is licensed under a Creative Commons Attribution 4.0 International License, which permits unrestricted use, distribution, and reproduction in any medium, provided the original work is properly cited.

\title{
Air Rage Arrangement Between the United Kingdom and Indonesia Based on the Tokyo Convention 1963
}

\author{
Naek Siregar \\ Faculty of Law, University of Lampung, Indonesia \\ naeksiregar69@gmail.com
}

\begin{abstract}
The implementation of international and national civil aviation must refer to applicable international and national legal norms to ensure the safety of passengers, flight crew, aircraft, and goods transported. To meet safety and security standards, each country must regulate flight security programs that refer to the regulations of the International Civil Aviation Organization (ICAO). Indonesia and the UK must meet these standards in dealing with perpetrators of air rage. Indonesia and the United Kingdom are the countries that participated in the ratification of the Convention on Offices and Certain Other Acts Committed on Board Aircraft, commonly called The Tokyo Convention 1963. Both countries have a legal obligation to implement the convention in their national law. A distinctive feature between Indonesia and the United Kingdom makes the implementation of the Tokyo Convention 1963 in that country different but still has the same goal of ensuring flight safety and security.
\end{abstract}

Keyword: Air Rage, United Kingdom, Indonesia, and The Tokyo Convention 1963.

How to Cite: Naek Siregar, "Air Rage Arrangement Between the United Kingdom and Indonesia Based on the Tokyo Convention 1963", Fiat Justisia, 13 (1), (2019).

DOI: https://doi.org/10.25041/fiatjustisia.v13no1.1472 


\section{A. Introduction}

The progress of science and technology, especially in the field of aviation, has created various types of air transportation that can cross various countries referred to as international flights. The implementation of civil aviation must refer to the provisions of international and national legal norms that apply to ensure flight safety and security. Aviation safety is a condition in which safety requirements are met in the utilisation of airspace, aircraft, airports, air transportation, flight navigation and supporting facilities and other public facilities. ${ }^{1}$ This flight safety can be achieved by realising the implementation of flights that are free from interference and unlawful actions. ${ }^{2}$ Aviation security and safety are fundamental to realising an orderly, organised, safe, secure and comfortable flight.

In a flight, the airline is represented by a cabin crew consisting of flight captains and flight attendants advising passengers to comply with every provision that is a safety and security standard in flight. However, sometimes passengers carry out unjustified actions on flights and even threaten flight safety. These actions are known as air rage. Air rage is behaviour carried out in an aircraft during a flight that can endanger other passengers, flight and flight officers. ${ }^{3}$ Passengers who behave dangerously are called unruly passenger. Behaviour that enters the air rage includes using a cellphone when the plane takes off, getting drunk on an aeroplane, disturbing and committing violence against other passengers, the captain and crew and damaging the aircraft including everything related to the flight. ${ }^{4}$

Air rage can be categorised as an illegal act as a result of passenger actions that threaten the safety of both the life and property of humans, as well as actions that can disrupt and hinder the development of international, and national air traffic and reduce public trust in the security of civil aviation. The International Air Transport Association (IATA) 2017 reports that the number of passengers involved in the case of air rage in 2017 increased by $50 \%$ from 2016 . The number of reports of an air rage incident in 2017 was 9.837 cases. $^{5}$ Therefore, unlawful acts in aviation are declared as a criminal act that raises human concern so that prevention and eradication must be carried out by every country by threatening severe penalties for perpetrators of flight crimes. ${ }^{6}$ However, legal enforcement

\footnotetext{
${ }^{1}$ Article 1 number 48 Law No. 1 on 2009 of Aviation.

${ }^{2}$ Article 20 number 2 The Chicago Convention 1944.

${ }^{3} \mathrm{http}: / /$ dictionary.cambridge.org

${ }^{4}$ Tekin Akgeyik, "Air Rage: Violence Toward Cabin Crew (A Study on Victimization of Unruly Passengers in Turkey)", Review of Business Research, 11 (3), (2011), p. 68.

${ }^{5}$ https://nypost.com/2017/12/08/air-rage-rose-50-percent-in-2017/

${ }^{6}$ General Explanation of Law No. 2 on 1976 of Ratification of the Tokyo Convention 1963, The Hague Convention 1970 and The Montreal Convention 1971.
} 
towards passengers that carry out air rage is difficult to implement; this is due to the jurisdictional unification of the international air law regulation. Aircraft registered countries have jurisdiction over criminal offences and criminal offences on board. ${ }^{7}$

The United Kingdom and Indonesia have ratified the Tokyo Convention 1963 and embedded in their national laws. However, the different forms of government and legal systems between the two countries resulted in differences in the implementation. The United Kingdom has ratified the Tokyo Convention 1963 as the United Kingdom Public General Act which means that it applies to all United Kingdom countries (Britain, Scotland, Wales and Northern Ireland). Their law enforcement is returned to their respective countries. Whereas Indonesia ratified the Tokyo Convention 1963 through Act No. 2 of 1976 concerning the Ratification of The Tokyo Convention 1963, the Hague Convention 1970 and the Montreal Convention 1971. Also, there was Law Number 1 of 2009 concerning Aviation to guarantee legal certainty in carrying out transportation systems nationwide. However, this law has no criminal sanctions against perpetrators of air rage. Therefore, law enforcement against perpetrators of air rage is based on the Indonesian Criminal Code (KUHP) which contains extraterritorial principles in crimes that threaten civil aviation safety. The issue approach used in this research is a normative juridical. ${ }^{8}$ This approach requires secondary data obtained from the review of legal material. The technique of data collection is done by library research.

\section{B. Discussion}

\section{Air Rage Arrangement in British Law}

The airspace of the United Kingdom is divided into 3 (three) jurisdictions namely England and Wales; Scotland; and Northern Ireland. However, the three jurisdictions are subject to one nationally regulated air law established by the Department for Transport (DfT). ${ }^{9}$ The institution that implements civil aviation in the United Kingdom is The Civil Aviation Authority (CAA).$^{10}$ The authority of the CAA comes from the Civil Aviation Acts 1982 and the 2012 amendments.

The United Kingdom is a country that participated in ratifying the Chicago Convention 1944 concerning International Civil Aviation which obliged the United Kingdom to carry out the contents of the agreement based on Pacta sun Servanda including provisions regarding rage water. The overall management of the State Safety Programme (SSP) and the delivery

\footnotetext{
${ }^{7}$ Article 3 paragraph 1, The Tokyo Convention 1963.

${ }^{8}$ Soerjono Soekanto, Penelitian Hukum Normatif, Jakarta: Rajawali Pers, (1990), pp. 14-15

${ }^{9}$ www.gov.uk/government/organisations/department-for-transport.

${ }^{10}$ www.caa.co.uk/home.
} 
of the UK aviation safety strategy is through the Safety Strategy Board (SSB). ${ }^{11}$ This is made up of senior representatives from the key aviation safety agencies. They are responsible for monitoring the safety performance of the UK aviation system and ensuring the state safety programme remains effective.

Therefore, the captain of an aircraft has full authority to halt passengers if the passenger shows the behaviour of air rage. Such behaviour endangers other passengers, flight crew and the flight itself. ${ }^{12}$ The captain must report passengers who endanger the flight based on the facts and reasons that occur. The facts and reasons will be sent to the diplomatic office or consular passenger country that behaves in air rage.

Aviation (Offences) Act 2003 is a law that applies throughout the United Kingdom to enforce laws related to aviation crime. Law enforcers can carry out prosecution without having to have an arrest warrant. It can be done based on the Police and Criminal Evidence Act 1984. Arrests can be carried out in several situations such as:

"An offence of contravening a provision of an Order in Council under section 60 of that Act (Air Navigation order) where the offence relates to (a) a provision which prohibits specified behaviour by a person in an aircraft towards or in relation to a member of the crew, or (b) a provision which prohibits a person from being drunk in an aircraft, in so far as it applies to passengers."

Provisions for arrests without warrants related to flight are also valid for the jurisdiction of Northern Ireland. However, in Scottish jurisdiction, Aviation (offence) Act 2003 only applies to criminal acts of terrorism in aircraft as stated in the Anti-terrorism, Crime and Security Act 2001:

"The following shall be inserted after section 82 (3) of the Antiterrorism, Crime and Security Act 2001- Where in Scotland, a constable has reasonable grounds for suspecting that a person has committed an offence contravening a provision of an Order in Council made under section 60 of the Civil Aviation Act (1982), and the offence relates to (a) a provision which prohibits specified behaviour by a person in an aircraft towards a member of the crew of the aircraft, (b) a provision which prohibits a person from being drunk in an aircraft, in so far as the provision applies to passengers, or (3) a provision which prohibits specified behaviour by a person, being behaviour which is likely to endanger."

\footnotetext{
11 https://www.caa.co.uk/Safety-initiatives-and-resources/How-we-regulate/State-safetyprogramme/Policy-and-resources/State-Safety-Programme-stakeholders/

${ }^{12}$ Section 94, Civil Aviation Act 1982.
} 
Penalties given to perpetrators of aviation crimes refer to the provisions of the Civil Aviation Act 1982 with a maximum sentence of 5 years in prison, a subsidiary of 2 years. ${ }^{13}$

\section{Air Rage Arrangement in Indonesian Law}

Indonesia is one of the member countries of the International Civil Aviation Organization (ICAO) which is obliged to international flights. ${ }^{14}$ ICAO and its member countries must ensure safety and order in the development of aviation, meeting the needs of the world community for safe, safe and comfortable air transportation. ${ }^{15}$ In carrying out these obligations, Indonesia ratified Law No. 1 of 2009 concerning Aviation and implementing regulations and the National Aviation Safety Program by ICAO provisions regarding the State Safety Program (SSP). ${ }^{16}$ The National Aviation Safety Program is a set of rules consisting of the SSP framework and material guidance from $\mathrm{ICAO}^{17}$ and activities to improve flight safety. This program aims to protect the safety, regularity and efficiency of flights in Indonesia through regulations, standards and procedures as well as the protection needed for passengers, flight crew, land personnel and the public from unlawful actions. ${ }^{18}$ Air rage is the behaviour of passengers who are angry and have a tendency to turn into acts of violence against flight crew and other passengers, trying to break through the cockpit, and even endanger the flight. Such behaviour is not always categorised as an act of terrorism, but behaviour that becomes an act of violence and destruction is classified as a form of crime according to Law No. 1 of 2009 concerning Aviation. The provisions of flight crimes are regulated in Articles 401-443.

\footnotetext{
${ }^{13}$ Aviation (Offence) Act 2003, Penalities. p 2.

${ }^{14} \mathrm{https} / / /$ www.icao.int/MemberStates/Member\%20States.English.pdf.

${ }^{15}$ Article 44, The Chicago Convention 1944.

${ }^{16}$ Article 308-311, Law No. 1 on 2009 of Aviation.

17 ICAO Document Number 9859, Development of the National Transportation Safety Program includes: (1) Policies on disclosure of responsibility (accountability), (2) Proactive risk management, (3) Aviation safety guarantees (Guarantees of State Safety) by guaranteeing the functioning of the control system, and (4) Improvement flight safety (Safety Promotion) by making sure everyone understands and focuses on their duties and responsibilities.

${ }^{18}$ Article 344, Law No. 1 of 2009 concerning Aviation. Unlawful acts in question are actions or experiments that endanger the safety of aviation and air transportation, including: (1) controlling aircraft in an unlawful manner, (2) carrying out in-service airplane destruction or destruction (3) ) holding people in an airplane or at an airport, (4) entering into an airplane, airport or aeronautical places by force, (5) carrying weapons, dangerous equipment or materials that can be used for legal action illegally, (6) using aircraft on land for actions that cause death, personal injury, damage to property or the surrounding environment, and (7) providing false information that endangers the safety of aircraft in flight or on land, passengers, flight crew air, land personnel or the general public at airports or other flight facilities.
} 
The behaviour of air rage in flight is determined as a criminal act regulate under the Criminal Code based on Law No. 4 of 1976 concerning Changes and Additions to Several Articles in the Criminal Code relating to the Expansion of the Applicability of Criminal Laws, Flight Crimes, and Crime against Aviation Facilities / Infrastructure. In the Criminal Code, the changes and additions are emphasised that:

\section{Article 479q}

"Whoever is in an aircraft commits an act that can endanger the security of an airplane in flight, subject to imprisonment for a maximum of five years."

\section{Article 479r}

"Anyone in an airplane carries out actions that can disrupt order and order in an airplane in flight, be sentenced to prison for a maximum of one year."

What is meant by this article with actions that are contrary to order and discipline in an airplane is to deliberately get drunk, make trouble, noise and so on? From the formulation of Article 479 of the Criminal Code above, the elements that are made into these actions include:

a. The existence of a legal subject: terms of "whoever (is)".

b. Unlawful actions: endanger security in airplanes and acts of disturbing order in aircraft in flight.

The application of sanctions for acts of crime that can disrupt order and order in aircraft in flight as stipulated in Law No. 1 of 2009 concerning Aviation, namely criminal sanctions that apply to criminal offences and criminal sanctions for criminal acts as crimes. This is in the formulation of Article 412 of Law No. 1 of 2009 concerning Aviation, namely:

\section{Article 412 paragraph 1}

"Everyone in an airplane during a flight commits an act that can endanger flight safety and security as referred to in Article 54 letter a shall be punished with a maximum imprisonment of 2 (two) years or a maximum fine of 500,000,000.00 IDR (five hundred million rupiahs)."

\section{Article 412 paragraph 2}

"Everyone in an airplane during a flight commits an act that violates the rules of flight, as referred to in Article 4 letter $b$ shall be punished with a maximum of 1 (one) year imprisonment or a maximum fine of 100,000,000.00 IDR (one hundred million rupiahs) "

\section{Article 412 paragraph 4}

"Everyone in an airplane during flight disrupts peace, as referred to in Article 54 letter $e$ shall be punished with a maximum of 1 (one) year imprisonment or a maximum fine of 100,000,000.00 IDR (one hundred million rupiahs). 
Law No. 1 of 2009 concerning Aviation adds one form of air rage in flights that are not included in the Criminal Code based on Law No. 4 of 1976 concerning Amendments and Additions to Several Articles in the Criminal Code relating to the Expansion of the Applicability of Criminal Laws. In enforcing aviation criminal law, Indonesia applies based on the principle of Lex specialis derogat lege generali, which is a special law that overrides general laws. ${ }^{19}$ Therefore, law enforcement related to air rage cases that occur in Indonesian jurisdiction is subject to Law No. 1 of 2009 concerning Aviation.

The case of air rage in Indonesia occurs in the flight of the Garuda Indonesia airline with flight number GA 863 on the Hong Kong-Jakarta route, Thursday, December 27, 2018. The chronology of the event is that a boy took the wrong seat. Stevany, the owner of the chair, came then feels acts with the boy harshly. Mother and child want to move to other seats, but Stevany's foot is stepped on by the child. Stevany was angrier at the child, and the child's mother became emotional because her child was scolded continuously.

The captain tried to calm the atmosphere by sending Stevany out of the cabin. Another passenger cheered Stevany; then he pushed the Captain until he almost fell. Physical contact with a flight crew is a violation of flight. The captain decided that the passenger named Stevany had been dropped from the plane because it was disturbing and posed a threat to safety, security and flight order. When interrogated by airport officials, Stevany is under the influence of alcoholic beverages. The aircraft captain has full authority in maintaining security, safety and order in flight. The implementation of this authority comes from the 1963 Tokyo Convention and Law No. 1 of 2009 concerning Aviation.

\section{Air Rage Arrangement Based on The Tokyo Convention 1963}

In 1963, an international meeting was held in Tokyo known as Convention on Offices and Certain Other Act, commonly called The Tokyo Convention 1963. Both Indonesia and the United Kingdom ratified the Tokyo Convention 1963. Indonesia has ratified through Act No.2 of 1976 concerning Ratification of the Tokyo Convention 1963, The Hague 1970 Convention, and the Montreal Convention 1971. Whereas, the United Kingdom ratified it on November 29, 1968. This Convention regulates law enforcement against criminal acts and deeds. Certain actions carried out in an aircraft. These actions include actions that are a violation of criminal law

\footnotetext{
${ }^{19}$ Wahyu Sasongko, (2013), Dasar-Dasar Ilmu Hukum, Lampung: Universitas Lampung, p.
} 29. 
or interfere with aviation security and safety. Criminal acts according to The Tokyo Convention 1963 must fulfil 4 (four) elements, namely:

a. Performed in the airplane.

b. The aircraft must be registered in the convention country

c. The aircraft must be on a flight over the high seas

d. The aircraft must be outside the territory of another country

The Tokyo Convention 1963 gave jurisdiction to the country where the aircraft was registered. ${ }^{20}$ The aircraft must be registered and the aircraft's nationality seen from where the aircraft is registered. ${ }^{21}$ Registration of aircraft is carried out so that the state is responsible for the safety of aircraft operations and each country must ensure that the aircraft registered to meet the applicable flight regulations. The aircraft is not registered in more than one country; the provision is to prevent jurisdictional conflict. ${ }^{22}$ Besides that, the Tokyo Convention 1963 gave airplane commanders the power to take necessary measures against anyone on board an aircraft that might endanger the aircraft. The commander in charge of removing passengers from the flight lost flight safety and security. Also, this convention gives member countries to take all necessary measures to restore flight control to aircraft commanders. $^{23}$

In the initial handling of air rage, the captain has the authority under the Tokyo Convention 1963 to:

\section{a. Authority to Withstand}

The captain is authorised to detain anyone who threatens aviation security and safety for reasons believed to ensure flight safety. This restraining authority is a step towards carrying out the captain's responsibility to (1) Protect the security of aircraft, people and property in aircraft, (2) Maintain order and discipline in aircraft, (3) Reduce passengers or parties that threaten security and submit it to the authorities.

\section{b. Authority to seek assistance}

The captain can ask the flight crew (flight attendant) to seek help from passengers to overcome the air rage incident. The nature of this authority is limited because it must be related to safety and carried out to prevent.

\section{c. Authority to land}

The captain can make an emergency landing at the nearest airport for security reasons or maintain order and discipline. All countries participating

\footnotetext{
${ }^{20}$ Article 3 (1) The Tokyo Convention 1963.

${ }^{21}$ Article 17 The Chicago Convention 1940.

${ }^{22}$ Article 18 The Chicago Convention 1940.

${ }^{23}$ Article 11 The Tokyo Convention 1963.
} 
in The Tokyo Convention 1963 must give their airports an emergency landing.

\section{d. Authority to submit to detainees}

The captain can hand over passengers or anyone who threatens flight safety and security to the authorities of each country that is the flight destination. The Montreal Convention 1971 strengthened this authority by giving the threat of severe punishment for perpetrators of air rage, especially attacking the flight crew.

In the implementation of The Tokyo Convention 1963, countries were given the freedom to implement it by the national laws. It is based on the legal characteristics of each different country such as the United Kingdom which adheres to Anglo Saxon and Indonesia adheres to Rechtstaat, Table 1.1. Comparison of Air Rage Regulations in the United Kingdom and Indonesia under the Tokyo Convention 1963

\begin{tabular}{|c|c|c|c|}
\hline No. & State & Air Rage Regulation & $\begin{array}{c}\text { Correlation } \\
\text { with Tokyo } \\
\text { Convention } \\
1963\end{array}$ \\
\hline 1. & United Kingdom & $\begin{array}{l}\text { Chicago Convention } \\
1944 \\
\text { Air rage goes against } \\
\text { Pacta Sunt Servanda } \\
\text { Aviation (Offences) Act } \\
2003 \\
\text { Law Enforcement } \\
\text { Police and Criminal } \\
\text { Evidence Act } 1984 \text { (Sec. } \\
\text { 60) } \\
\text { Prohibit unpleasant } \\
\text { passenger behaviour in } \\
\text { flight. } \\
\text { The Anti-terrorism, } \\
\text { Crime and Security Act } \\
\text { 2001 (Sec. } 82 \text { (3)) } \\
\text { Passenger unpleasant } \\
\text { behaviour in more } \\
\text { specific flights } \\
\text { (contaminated with } \\
\text { alcohol, hurting cabin } \\
\text { crew, and hurting other }\end{array}$ & $\begin{array}{c}\text { Ratified or } \\
\text { accessed on } \\
\text { November } 29^{\text {th }} \text {, } \\
1968\end{array}$ \\
\hline
\end{tabular}




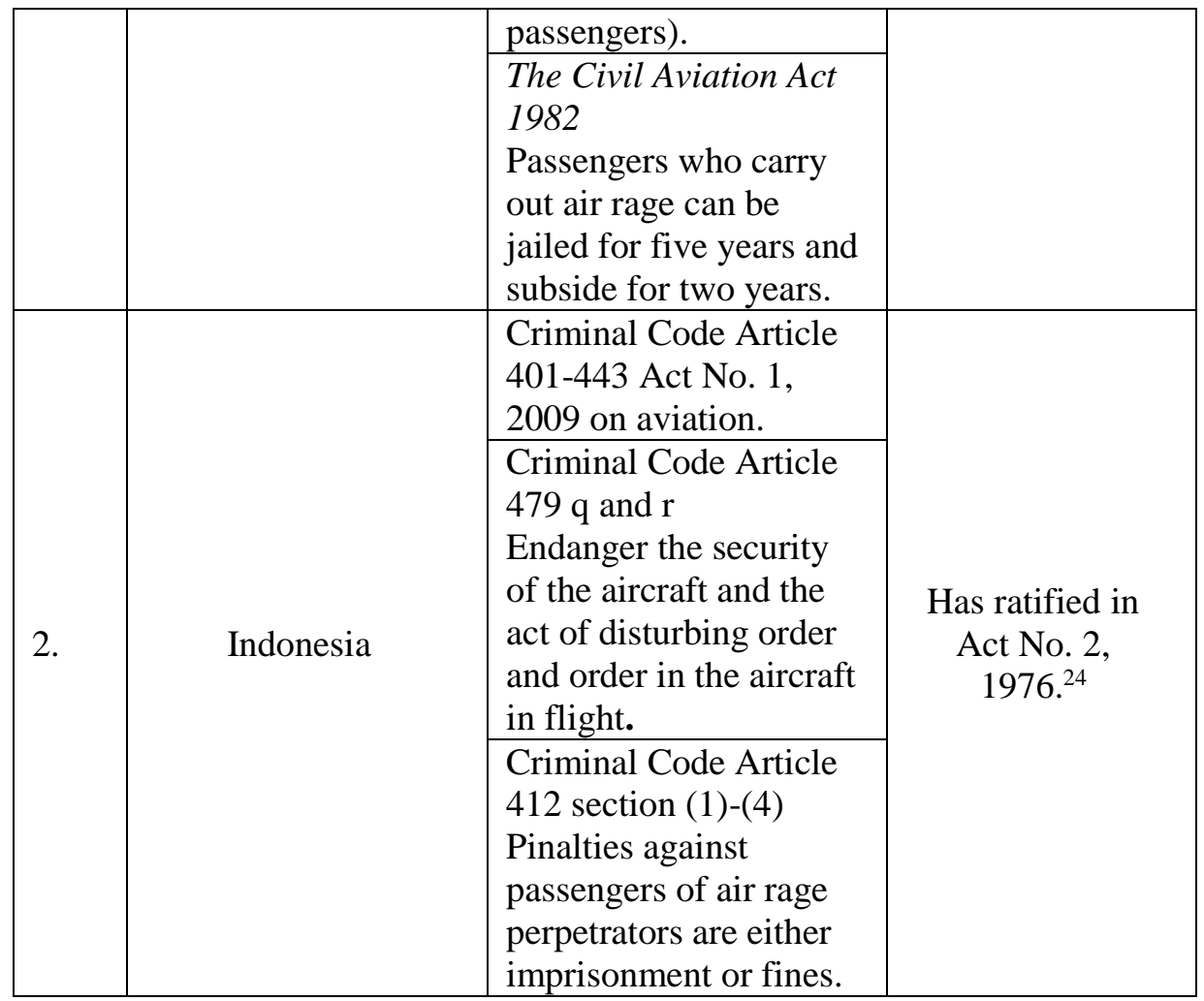

\section{Conclusion}

Air rage Arrangement in The Convention on Offices and Certain Other Act is an illegal action or The Tokyo Convention 1963 that can threaten international flights. The Tokyo Convention 1963 gave great authority to the captain of the aircraft to take actions that were deemed necessary to prosecute passengers who behaved with air rage, including the authority to detain, the authority to seek assistance, the authority of an emergency landing, and the authority to submit to detention.

Air rage regulation in the national laws of the United Kingdom and Indonesia is different Law enforcement related to the flight spirit of state spirits includes the countries of the United Kingdom (England, Wales, Scotland and Northern Ireland) which are subject to The Civil Aviation 1982, Aviation (Offence) Act 2003. In the law, criminal sanctions can be imposed the perpetrator of aviation crime is a 5-year jail sentence of 2 years. Indonesia has a Criminal Code based on Act No. 4 of 1976 concerning

${ }^{24}$ Law No. 2 of 1976 concerning Ratification of the Tokyo Convention 1963, The Hague 1970 Convention, and the Montreal Convention 1971. 
Changes and Additions to Several Articles in the Criminal Code relating to the Expansion of the Applicability of Provisions for Criminal Laws, Aviation Crimes, and Crimes against Aviation Facilities / Infrastructure. In this provision, the behaviour of air rage is limited to behaviour that threatens the safety of the flight and the order of the aircraft. Also, Indonesia has special aviation-related laws, namely Act No. 1 of 2009 concerning Aviation in which there are criminal provisions that extend the coverage of air rage not only limited to behaviour that threatens aviation security and airplane rules but adds behaviour that disturbs the peace.

\section{A. Book}

\section{Bibliography}

Sasongko, Wahyu. (2013). Dasar-Dasar Ilmu Hukum. Lampung: Universitas Lampung.

Soekanto, Soerjono. (1990). Penelitian Hukum Normatif. Jakarta: Rajawali Pers.

\section{B. Journal}

Tekin Akgeyik, "Air Rage: Violence Toward Cabin Crew (A Study on Victimization of Unruly Passengers in Turkey)", Review of Business Research, 11 (3), (2011).

\section{World Wide Web}

http://dictionary.cambridge.org . https://www.caa.co.uk/Safety-initiatives-and-resources/How-we regulate/State-safety-programme/Policy-and-resources/State-SafetyProgramme-stakeholders/. https://www.icao.int/MemberStates/Member\%20States.English.pdf www.caa.co.uk/home.

www.gov.uk/government/organisations/department-for-transport https://nypost.com/2017/12/08/air-rage-rose-50-percent-in-2017/

\section{Legislation}

Aviation (Offence) Act 2003, Penalties.

Civil Aviation Act 1982.

General Explanation of Act No. 2 of 1976 concerning Ratification of the Tokyo Convention 1963, The Hague Convention 1970 and The Montreal Convention 1971.

ICAO Document Number 9859 concerning Safety Management Manual. Law No. 1 of 2009 concerning Aviation.

Law No. 2 of 1976 concerning Ratification of the Tokyo Convention 1963. The Hague 1970 Convention, and the Montreal Convention 1971. 
The Chicago Convention 1944.

The Tokyo Convention 1963. 